\title{
VARICELLA OF THE CORNEA TREATED WITH 5-IODO-2'-DEOXYURIDINE*
}

\author{
BY \\ J. E. CAIRNS \\ London
}

VARICELla of the cornea appears to be a rare complication of the disease (DukeElder, 1938; Banks, 1949). Since the varicella virus is of the DNA-containing group, modification of the course of superficial lesions by means of 5-iodo-2'-deoxyuridine (IDU) is a possibility, this agent having been used with some success against another DNA-containing virus, that of herpes simplex (Corrigan, Gilkes, and Roberts, 1962; Davidson, 1962; Kaufman, Martola, and Dohlman, 1962; Luntz and MacCallum, 1963).

\section{Case Report}

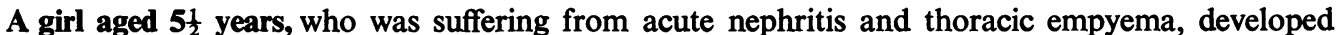
a rash typical of varicella. On the sixth day after the rash first appeared, a lesion developed at the limbus of the left eye. This lesion, which consisted of a clear vesicle set deeply in the substance of the limbus, was surrounded on the outer aspect by a halo of small haemorrhages in the conjunctiva, and on the corneal aspect by a narrow (approximately $1 \mathrm{~mm}$.) zone of corneal cloudiness. Beyond this the cornea appeared normal and there was no anterior uveitis. The patient, although fully alert and active, appeared to notice no discomfort from the eye (Fig. 1).

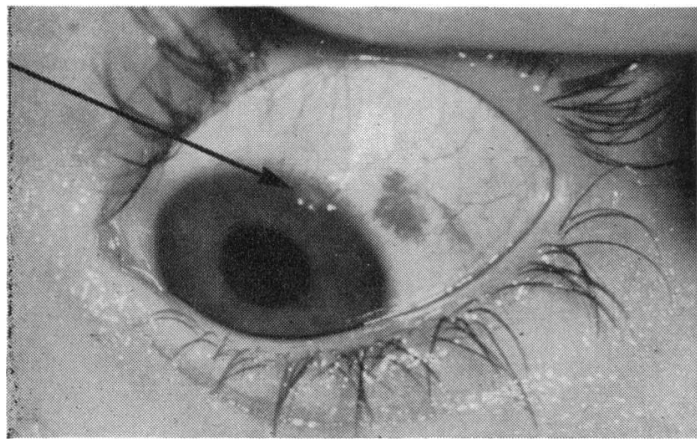

FIG. 1.-The lesion 24 hours after its appearance.

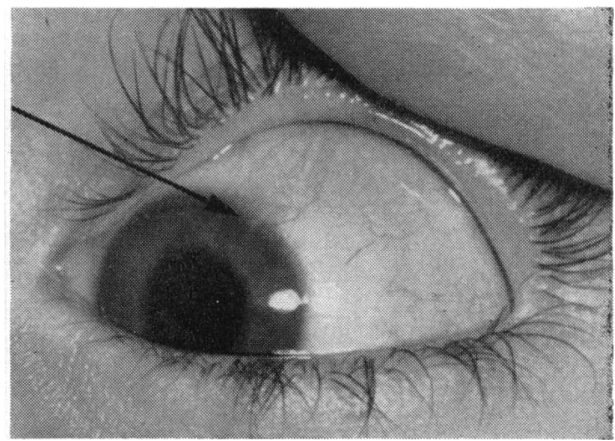

Fig. 2.-The lesion at the end of 5 days treatment with IDU.

Treatment with oculentum IDU 0.5 per cent. was begun when the lesion had been present for 24 hours, and applications were made 2-hrly night and day for 5 days. The lesion began to regress during the second day of treatment, and by the end of the course it appeared as a fine white spot in the limbal stroma (Fig. 2). The lesion remained in this state for the ensuing 5 weeks. The patient has not been seen again, but no report of further eye symptoms has been received from her parents, who were advised to watch for redness and photophobia. 


\section{Discussion}

Descriptions of the appearance and views as to the prognosis of corneal varicella lesions are infrequent in the literature. Duke-Elder (1938) refers to cases of direct corneal involvement by varicella described by Oppenheimer (1905) and Pickard (1936) in which resolution occurred without complication, and to the case described by Sommer (1909), in which conjunctival varicella was accompanied by a corneal lesion, which also followed a benign course.

Thomas (1955), describing varicella lesions of the cornea, stated that the lesion was not serious unless it occurred in the limbal region when it might extend to involve the cornea; such involvement might be superficial or might resemble disciform keratitis. The prognosis was generally good, except for the scarring which might be considerable. Although Thomas cited no case report in support of these statements, it is noted that patients are occasionally seen who attribute a corneal opacity to chickenpox in the past; on the other hand, the possibility of a concurrent herpes simplex corneal infection at the time of the chickenpox must be borne in mind.

Since the possibility of serious corneal disease appears to exist, and since an agent with a specific action against DNA-containing viruses is now available, it appears reasonable to treat varicella lesions involving the deeper layers of the cornea with IDU, which was done in the case described above without ill-effects.

\section{Conclusion}

Corneal varicella is rare and its course and prognosis somewhat uncertain. It seems right to regard those lesions involving the deeper layers of the cornea as potentially serious, and to treat them with IDU. No ill-effects were observed in one such case, in which the lesions healed without complication.

I am indebted to Mr. J. H. Dobree for permission to describe his case. My thanks are also due to the Photographic Department, St. Bartholomew's Hospital, to Mrs. E. Cole for the secretarial work, and to Messrs. Smith, Kline and French for trial samples of IDU.

\section{REFERENCES}

Banks, H. S. (1949). “The Common Infectious Diseases", p. 194. Arnold, London.

Corrigan, M. J., Gilkes, M. J., and RoberTs, D. St. C. (1962). Brit. med. J., $2,304$.

DAVIDSON, S. I. (1962). Lancet, 2, 1326.

Duke-Elder, S. (1938). "Text-book of Ophthalmology", vol. 2, pp. 1653, 1907. Kimpton, London.

Kaufman, H. E., Martola, E., and Dohlman, C. (1962). 'Arch. Ophthal. (Chicago), 68, 235.

LunTZ, M. H., and MacCallum, F. O. (1963). Brit. J. Ophthal., 47, 449.

OPPENHEIMER, E. H. (1905). Dtsch. med. Wschr., 31, 833.

PICKARD, R. (1936). Brit. J. Ophthal., 20, 15.

SOMMER, G. (1909). Wschr. Ther. Hyg. Auges, 12, 205.

Thomas, C. I. (1955). "The Cornea", p. 637. Thomas, Springfield, Ill. 